Arch. Tierz., Dummerstorf 51 (2008) 5, 487-497

\author{
${ }^{1}$ Institute of Land Use Systems and Landscape Ecology, Leibniz-Centre for Agricultural Landscape Research (ZALF), \\ Müncheberg, Germany \\ ${ }^{2}$ Agricultural Research Station, Leibniz-Centre for Agricultural Landscape Research (ZALF), Paulinenaue, Germany
}

ANDREAS FISCHER ${ }^{1}$, GISBERT SCHALITZ ${ }^{2}$ and AXEL BEHRENDT ${ }^{2}$

\title{
Comparative studies on the grazing behaviour of fallow deer and sheep in winter
}

\begin{abstract}
During two successive winter periods the ingestive behaviour of female fallow deer and Skudde mother sheep was observed during the day-light periods of a day in fourteen-day intervals. The animals were grouped together on an extensively used permanent fen pasture area with a stock of 0.5 large-animal units (which corresponds to $250 \mathrm{~kg}$ of animal living mass) per hectare. Sufficient quantities of fresh grass and hay were available.

The results obtained show that the animals maintained their species-specific ingestive behaviour despite common keeping. As compared to fallow deer, the sheep spent markedly longer time with ingestive activities. There were only rare instances of rivalry and conflict (over grazing positions or hay-feeding points) between the two species.

The animals of the two groups of species under examination are well adapted to the prevailing climatic conditions. They proved to be able to respond to extreme weather conditions as cold periods and snow storms. It can be rightfully stated that they are able to spend the winter in the open without harm to their health.

Outdoor keeping in the winter period can be regarded as suitable for fallow deer and Skudde sheep in northeast Germany.
\end{abstract}

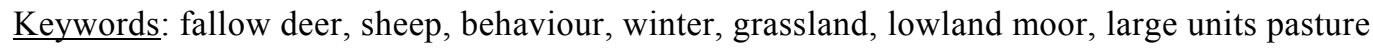

\section{Zusammenfassung}

Titel der Arbeit: Vergleichende Studien über das Nahrungsaufnahmeverhalten von Damwild und Schafen im Winter

In zwei aufeinander folgenden Winterperioden wurde in 14-tägigem Rhythmus das Nahrungsaufnahmeverhalten von weiblichem Damwild und Mutterschafen der Rasse Skudde während des Lichttages beobachtet. Die gemeinsame Haltung erfolgte auf einer extensiv geführten Niedermoor-Standweide mit einer Besatzstärke von $0,5 \mathrm{GV} /$ ha. Zur Nahrungsaufnahme standen den Tieren ausreichend Weidegras und Heu zur Verfügung.

Die Ergebnisse zeigen, dass trotz gemeinsamer Haltung die Tiere ihr artspezifisches Nahrungsaufnahmeverhalten aufrechterhalten. Im Vergleich zum Damwild weisen Schafe deutlich zeitlich längere Nahrungsaktivitäten auf. Zwischenartliche Konkurrenz- und Konfliktsituationen um Nahrungsquellen (Grasensstandorte bzw. Heufütterungsplatz) konnten nur in wenigen Fällen registriert werden.

Die Vertreter der beiden untersuchten Tierarten sind an die vorherrschenden klimatischen Bedingungen gut adaptiert. Sie erweisen sich als reaktionsfähig gegenüber Witterungsextremen, wie Kältephasen oder Schneestürme. Es ist einzuschätzen, dass sie unter den beschriebenen Verhältnissen gesund überwintern.

Die Winterfreilandhaltung von Damwild und Schafen der Landrasse Skudde ist für Nordostdeutschland als tierartgerecht einzustufen.

Schlüsselwörter: Damwild, Schaf, Verhalten, Winter, Grasland, Niedermoor 


\section{Introduction}

In north-east Germany (i.e. the federal states of Mecklenburg-Vorpommern and Brandenburg) mother cows (approx. $40 \%$ of total stock) and animals kept in paddocks (predominantly fallow deer and red deer) are left in the open all over the year. A combination of sheepfold tending and outdoor keeping is still widely common for sheep. This means that flocks are tended on permanent green land and crop areas during the day in winter. If overall conditions allow so, outdoor keeping of sheep in paddocks is increasingly accepted all over the year.

Substantive reasons to favour winter pastures are the reduced costs for the purchase, transport, and storage of hay, the maintenance of buildings, the clearance and distribution of manure, and the input of labour. In addition, the fodder grown on fen pastures is hardly any more completely consumed by the animals during the vegetation period because of the relatively low number of stock in the region $(0.5$ to 1.0 large-animal units per ha). In addition to mother cows should, therefore, sheep increasingly be used to graze on fen areas in order to keep these areas open (FISCHER et al., 2007).

There is only relatively small information available concerning the grazing behaviour of jointly grouped fallow deer and sheep in winter.

Ethological analyses for the description of the status of animals under specific environmental conditions are suitable to assess maintenance methods as they allow for the characterisation of the biological quality of the conditions in which the animals are kept (WASSMUTH et al., 2001). Since numerous life processes are linked with the lengths of photo periods (circadian pattern) the recording of animal behaviour helps understand regularities and offers a sensitive bio-indicator by which an early detection of strains and disorders in the relation between living organisms and the environment is possible (TEMBROCK, 1987).

The present contribution analyses results concerning the ingestive behaviour of fallow deer and sheep in winter. Such results provide a basis for establishing and managing winter pastures that correspond with the specific requirements of the animals.

\section{Materials and methods}

The study on the joint keeping of fallow deer and sheep on winter pastures were carried out in a paddock covering a territory of about two hectares in a fen area near the village of Paulinenaue in the Havelländische Luch area in the German federal state of Brandenburg. This type of relief-structured low-bottom fen is to be found on about 60,000 ha of land in north-east Germany. The altitudes of pastures vary between 28.5 and $29.3 \mathrm{~m}$ above sea level.

Extensive measures which were carried out over several years resulted in a drop of yield from 8,000 to $10,000 \mathrm{~kg}$ to $6,000 \mathrm{~kg}$ of dry matter per ha. (SCHALITZ, 2001). According to LEIPNITZ (2001), plant stands are characterised by the dominant species Agropyron repens, Poa pratensis L., and Poa trivialis L., and there is a high percentage of Urtica dioica L. and Cirsium arvense L., supplemented by low-yield ( $<5 \%)$ Taraxacum officinale L. and Thalictrum flavum $L$.

The paddock features a shelter which is covered on three sides where hay is offered in racks and which is available to the animals ad libitum. 
In its northern part, the paddock includes a $400 \mathrm{~m}^{2}$ coppice of willow trees which is almost exclusively entered by fallow deer.

The jointly grouped sheep and fallow deer were counted and registered by the pasture activities in the winter periods of 1999/2000 (I) and 2000/2001 (II). There were eight adult females covered in autumn. Altogether there were eight (in the period I) and nine (in the period II) fallow deer females, and nine (in the period I) and ten (in the period II) Skudde mother sheep. There were approximately 0.5 large animal units (which corresponds to $250 \mathrm{~kg}$ of animal living mass) per ha. The fallow deer had grown their winter hair in October while the sheep's fleece featured a staple depth of about $7 \mathrm{~cm}$.

In both observation periods from early November till late February, the grazing activities of the sheep and the fallow deer were visually observed in a two-weeks rhythm at intervals of five minutes over the day-light periods of a day. On some days, observation was obscured by fog or haze in the morning or in the evening. This explains the partly slight differences between the meteorologically exact duration of the day-light period of a day and the actual duration of observation.

Result assessment is based on the total ingesting time, duration of grazing, the frequency of grazing periods, the duration of hay intake, the frequency of hay intake, and locomotion performance.

The mean values of the observation period and registered climatic data are shown in Table 1.

Table 1

Comparison of mean values of observation duration and selected climatic data of observation days/Paulinenaue location (Mittelwertvergleich der Beobachtungsdauer und ausgewählter klimatischer Daten der Untersuchungstage/Standort Paulinenaue)

\begin{tabular}{lcccccc}
\hline Winter period & $\begin{array}{c}\text { Day light time } \\
\mathrm{min} \cdot \mathrm{d}^{-1}\end{array}$ & $\begin{array}{c}\text { Temperature } \\
(2 \mathrm{~m}){ }^{\circ} \mathrm{C}\end{array}$ & $\begin{array}{c}\text { Precipitation } \\
\text { amount } \\
\mathrm{mm} \cdot \mathrm{d}^{-1}\end{array}$ & $\begin{array}{c}\text { Wind velocity } \\
\mathrm{m} \cdot \mathrm{s}^{-1}\end{array}$ & $\begin{array}{c}\text { Relative humidity } \\
\%\end{array}$ \\
\hline $\mathrm{I}$ & $\overline{\mathrm{X}}$ & 593.3 & 2.6 & 2.4 & 3.5 & 86.2 \\
& $\mathrm{~S}$ & 47.7 & 5.1 & 3.8 & 1.9 & 10.5 \\
$\mathrm{II}$ & $\overline{\mathrm{x}}$ & 580.6 & 2.7 & 0.8 & 2.5 & 89.2 \\
& $\mathrm{~s}$ & 45.9 & 3.4 & 1.6 & 1.2 & 8.8 \\
\hline
\end{tabular}

The statistical assessment of the data material was aided by SPSS software which is based on the application of a 2 -factorial variance analysis $(A \cdot B-n)$.

Correlations between features are defined by help of correlation coefficients (Pearson).

\section{Results and discussion}

\section{Total ingesting time}

In the present investigations was found marked differences between sheep and fallow deer in terms of total ingesting time (Table 2). Sheep spend much longer time for eating than fallow deer. On an average, they are occupied with feed intake for $5.8 \mathrm{~h}$ on a winter day (58.9\% of the day light period of a day). As compared to that, fallow deer eat for $3.6 \mathrm{~h}$ (37.14\% of the day-light period of a day). As can be seen from Table 2, ingesting time shows remarkable differences between the two winter periods. Like the other parameters under examination, species-specific characteristics vary to a remarkably high degree between the observation days within one winter period (see Figures 1-4). 

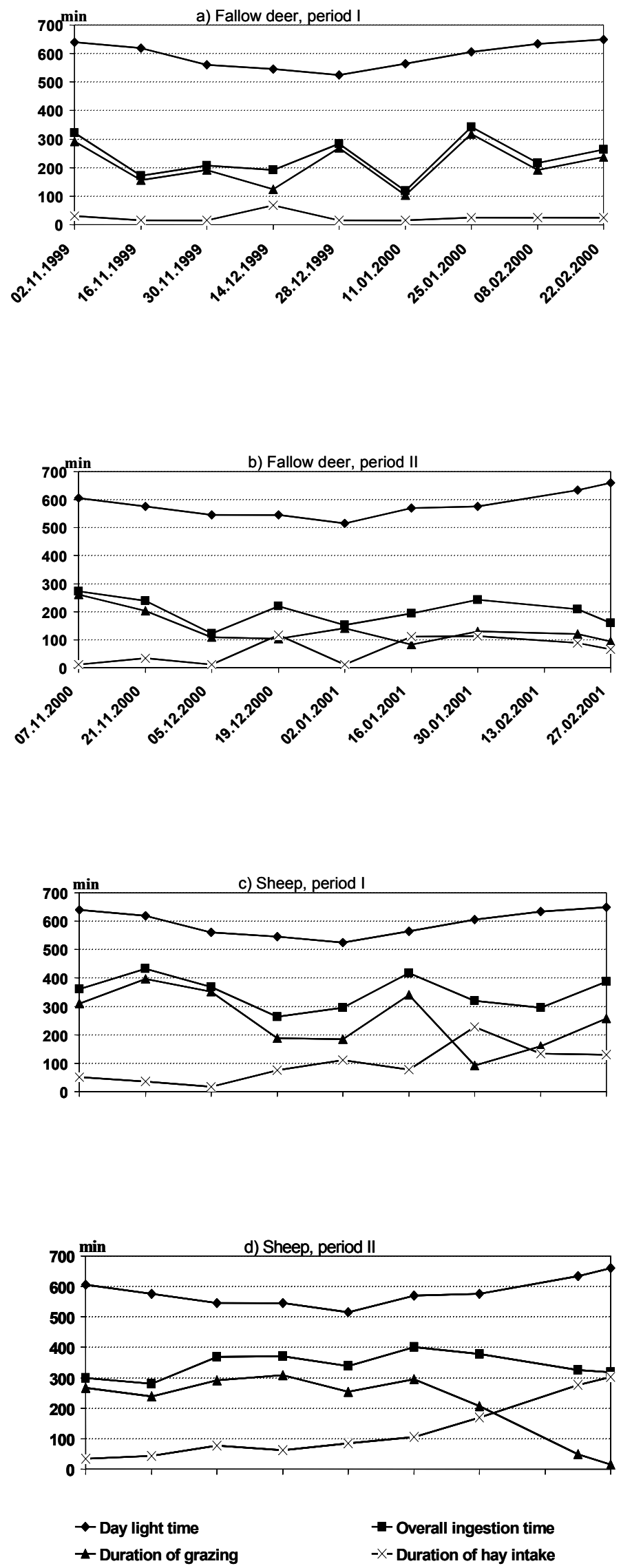

Fig. 1-4: Day light time and duration of activities of fallow deer and sheep on individual observation days in the winter period I and II (Tageslichtlänge und Dauer der Aktivitäten von Damwild und Schafen an den einzelnen Beobachtungstagen in den Winterperioden I und II) 
Table 2

Comparison of mean values of total ingesting time $\left(\mathrm{min} \cdot \mathrm{d}^{-1}\right)$

(Mittelwertvergleich der Gesamtfresszeit $\left[\mathrm{min} \cdot \mathrm{d}^{-1}\right]$ )

\begin{tabular}{|c|c|c|c|c|}
\hline Winter period & & Fallow deer & Sheep & Total year \\
\hline I & $\begin{array}{l}\overline{\mathrm{x}} \\
\mathrm{s} \\
\% \text { (Day light time) }\end{array}$ & $\begin{array}{r}234.7 \\
73.4 \\
39.6\end{array}$ & $\begin{array}{r}349.1 \\
58.7 \\
58.8\end{array}$ & $291.9^{\text {n.s. }}$ \\
\hline II & $\begin{array}{l}\overline{\mathrm{x}} \\
\mathrm{s} \\
\% \text { (Day light time) }\end{array}$ & $\begin{array}{r}201.2 \\
48.8 \\
34.7\end{array}$ & $\begin{array}{r}342.2 \\
39.7 \\
58.9\end{array}$ & $271.7^{\text {n.s. }}$ \\
\hline Total species & $\begin{array}{l}\overline{\mathrm{x}} \\
\% \text { (Day light time) }\end{array}$ & $\begin{array}{l}218.0^{\text {n.s. }} \\
37.1\end{array}$ & $\begin{array}{r}345.6^{*} \\
58.9\end{array}$ & \\
\hline
\end{tabular}

Significant difference (t-test) species and year $=38.4$; significant difference interactions $=54.3 ;$ n.s. $=$ not significant; ${ }^{*} p<0.05$

This comparison of data leads to the conclusion that sheep show shorter, and possibly more intensive, ingestive activities in winter.

The values obtained regarding fallow deer are comparable with information from pertinent literature.

PIETROWSKI (1984) records an annual mean ingestion time of $42 \%$ (20 to $56 \%$ ).

According to BAMBERG (1985), total ingesting time sums up to 55 to $60 \%$ of a $24 \mathrm{~h}$ day in spring, 45 to $70 \%$ in summer, $55 \%$ in autumn, and 35 to $50 \%$ in winter. The time spent on ingestive activities essentially depends on the distribution of fodder sources and their location with regard to resting areas that offer rich cover. Consequently, animals living in close vicinity to their fodder sources in small paddocks need only shorter ingesting periods than animals living in open land.

ZEEB (1990) recorded that, on an average, animals of this species in paddocks are occupied with ingestion for 34 to $39 \%$ of the time in May and June.

Information on the duration of daily ingestion time of sheep widely varies in pertinent literature. According to TRIBE (1950), this time is limited to about 11 to $12 \mathrm{~h}$. ARNOLD and DUDZINSKI (1978) give a time frame of 3 to $13 \mathrm{~h} \cdot \mathrm{d}^{-1}$. Results obtained by BUENO and RUCKEBUSCH (1978) vary between 7.5 and $9.8 \mathrm{~h} \cdot \mathrm{d}^{-1}$. ARNOLD (1984) arrives at result of $4.4 \mathrm{~h} \cdot \mathrm{d}^{-1}$, and FISCHER (2001) recorded the grazing time of two races of sheep. While, according to these records, Merion mutton sheep grazed $7.5 \mathrm{~h} \cdot \mathrm{d}^{-1}$ during the vegetation period, Skudde sheep spent $8.2 \mathrm{~h} \cdot \mathrm{d}^{-1}$ with grazing. The results were mainly obtained from observations during the summer months, and many analyses do not take into consideration nocturnal activities. Both species are more active during the day than during the night (UECKERMANN and HANSEN, 1983; PORZIG and SAMBRAUS, 1991), which justifies the absence of nocturnal observations.

\section{Duration of grazing}

In both winter periods the animals had ad libitum access to sufficient quantities of fresh green fodder and hay. They were free to choose between these types of fodder. As can be seen from Table 3, sheep graze longer than fallow deer. There are, however, significant differences between the winter periods within the two groups: both fallow deer and sheep spent markedly more time with grazing in the winter period I than during the following observation period. Although the animals were jointly kept in a paddock, no common ingestion rhythm developed between fallow deer and sheep, with the individuals of both species grazing mainly in their own 
groups. Species-specific ingestion behaviour was apparently maintained and not mutually influenced. During those phases when both groups were eating they used different sections of the paddock at a time. Accordingly, both groups grazed on the same areas at different times. Locomotion during grazing reduced the distance between the two groups to about 20 meters. Reduced availability of grass (in early February) resulted in greater distances between the individuals of the two groups during grazing.

Table 3

Comparison of mean grazing time $\left(\mathrm{min} \cdot \mathrm{d}^{-1}\right)\left(\right.$ Mittelwertvergleich der Grasenszeit $\left.\left[\mathrm{min} \cdot \mathrm{d}^{-1}\right]\right)$

\begin{tabular}{llccc}
\hline Winter period & & Fallow deer & Sheep & Total year \\
\hline I & $\overline{\mathrm{x}}$ & 208.9 & 253.8 & $231.3^{\text {n.s. }}$ \\
& $\mathrm{s}$ & 75.0 & 102.9 & \\
\% (Day light time) & 35.2 & 42.8 & \\
II & $\overline{\mathrm{x}}$ & 138.4 & 213.9 & $176.1^{\text {n.s. }}$ \\
& $\mathrm{S}$ & 57.8 & 108.1 & \\
& $\%$ (Day light time) & 23.8 & 36.8 & \\
Total species & $\overline{\mathrm{x}}$ & $173.7^{\text {n.s. }}$ & $233.8^{*}$ \\
& \% (Day light time) & 29.6 & 39.8 \\
\hline
\end{tabular}

Significant difference (t-test) species and year $=60.0 ;$ significant difference interactions $=84.9 ;$ n.s. $=$ not significant; ${ }^{*} \mathrm{p}<0.05$

Temperatures below freezing point, prolonged periods of precipitation, and low snow blankets do not prevent the animals from grazing. SCHALITZ and FISCHER (1995) recorded similar patterns of behaviour of young cattle. According to ZEEB (1990), rain does not affect grazing activities of fallow deer.

\section{Frequency of grazing periods}

The quoted observation results demonstrate a reduction of frequency with shorter day-light periods.

In this regard, the present material shows only minor differences between the two animal species (Table 4). The total average of grazing periods is 2.8 for fallow deer and 3.2 for sheep during the day-light period of a day. Due to the longer duration of grazing periods the average time is $79.1 \mathrm{~min}$ for sheep, while the average is $69.3 \mathrm{~min}$ for fallow deer.

Table 4

Mean frequency of grazing periods $\left(n \cdot d^{-1}\right)\left(\right.$ Durchschnittliche Anzahl Grasensperioden $\left.\left[n \cdot d^{-1}\right]\right)$

\begin{tabular}{llccc}
\hline Winter period & & Fallow deer & Sheep & Total year \\
\hline I & $\overline{\mathrm{x}}$ & 2.7 & 3.3 & $3.0^{\text {n.s. }}$ \\
& $\mathrm{s}$ & 0.7 & 1.0 & $3.0^{\text {n.s. }}$ \\
II & $\overline{\mathrm{x}}$ & 3.0 & 3.0 & 1.1 \\
\\
\multirow{2}{*}{ Total species } & $\mathrm{s}$ & 1.6 & $3.2^{\text {n.s. }}$ & \\
\hline
\end{tabular}

Significant difference ( $\mathrm{t}$-test $)$ species and year $=0.78$; significant difference interactions $=1.10 ;$ n.s. $=$ not significant

Over the day-light period of a day, alternate grazing and non-grazing phases can be observed.

The amount of feed taken up at a time, and the duration of time needed for that is not an autonomous variable but depends on various factors (MEEKERS and MYERS, 1979; BAILE and DELLA-FERA, 1981). Time is more important for the regulation of ingestion than frequency (LEVITSKY, 1993). 
The number of grazing periods is influenced by climate, breed, local conditions, and quantity and quality of fodder (PORZIG and SAMBRAUS, 1991). Previous publications record between 1 and 7 periods for sheep (CZAKO et al., 1979).

According to FISCHER (2001), the mean number of periods is 6.2 per day for Skudde sheep.

VAN ACKEN (1972) recorded 6 to 10 browsing periods for paddock-kept fallow deer in summer and two to three periods in winter during the day-light period of a day with intervening resting periods.

\section{Duration of hay intake}

In both winter periods, the duration of hay intake, like the duration of grazing periods, differs sharply between fallow deer and sheep (Table 5). In the case of sheep, time is markedly longer than in the case of fallow deer.

Table 5

Comparison of mean duration of hay intake $\left(\min \cdot \mathrm{d}^{-1}\right)\left(\right.$ Mittelwertvergleich der Heuaufnahmedauer $\left.\left[\mathrm{min} \cdot \mathrm{d}^{-1}\right]\right)$

\begin{tabular}{llccc}
\hline Winter period & & Fallow deer & Sheep & Total year \\
\hline I & $\overline{\mathrm{x}}$ & 25.8 & 95.3 & $60.6^{\text {n.s. }}$ \\
& $\mathrm{S}$ & 16.7 & 64.2 & \\
& $\%$ (Day light time) & 4.4 & 16.1 & \\
II & $\overline{\mathrm{X}}$ & 62.8 & 128.3 & $95.5^{\text {n.s. }}$ \\
& $\mathrm{S}$ & 46.0 & 99.8 & \\
& \% (Day light time) & 10.8 & 22.1 & \\
Total species & $\overline{\mathrm{x}}$ & $44.3^{\text {n.s. }}$ & $111.8^{*}$ \\
& \% (Day light time) & 7.6 & 19.0 \\
\hline
\end{tabular}

Significant difference $\left(\mathrm{t}\right.$-test) species and year $=43.6 ;$ significant difference interactions $=61.7 ; \mathrm{n} . \mathrm{s} .=$ not significant; ${ }^{*} \mathrm{p}<0.05$

The two groups of animals usually ate hay independently of one another. While the one group was eating, the other one either rested/ruminated, or grazed. There was only one instance when rivalry developed over fodder. In this case, the sheep group forced the fallow deer away from the hay racks. Similar inter-specific behaviour is described for fallow deer and red deer by BARTOS et al. (1996) In that case, fallow bucks attacked eating red deer until the latter left the feeding point although there was abundant fodder.

\section{Frequency of hay intake}

There are distinct differences in the frequency of hay in intake between the two species (Table 6). The hay feeding points are more often frequented by sheep than by fallow deer.

Table 6

Mean frequency of hay intake periods $\left(n \cdot d^{-1}\right)$

(Durchschnittliche Anzahl der Aufnahmeperioden von Heu $\left[\mathrm{n} \cdot \mathrm{d}^{-1}\right]$ )

\begin{tabular}{llccc}
\hline Winter period & & Fallow deer & Sheep & Total year \\
\hline I & $\overline{\mathrm{x}}$ & 1.1 & 3.4 & $2.3^{\text {n.s. }}$ \\
& $\mathrm{S}$ & 0.3 & 2.4 & $2.8^{\text {n.s. }}$ \\
II & $\overline{\mathrm{x}}$ & 2.3 & 3.3 & \\
& $\mathrm{~s}$ & 1.0 & 1.5 & \\
Total species & $\overline{\mathrm{x}}$ & $1.7^{\text {n.s. }}$ & $3.4^{*}$ & \\
\hline
\end{tabular}

Significant difference $\left(\mathrm{t}\right.$-test) species and year $=1.01 ;$ significant difference interactions $=1.43 ; \mathrm{n} . \mathrm{s} .=$ not significant; ${ }^{*} \mathrm{p}<0.05$ 
Correlation between duration day light time, total ingestion time, and duration of grazing and hay intake

The Figures 1-4 are graphic representations of day light time and characteristics of ingestive activities on individual observation days. Day light time and characteristics are shown separately for each winter period and animal species. The registered data show remarkable variability within the groups and during the observation periods. With winter progressing, growing relevance apparently attaches to hay intake particularly for sheep (Figures 3 and 4).

Correlations between the registered data are shown in the following.

As seen from Table 7, no significant correlation exists between day light time and ingestion parameters. However, there is a significantly positive correlation between total ingestion time and grazing time. On the other hand, there are significantly negative correlation coefficients between grazing time and the duration of hay intake Hay quality varied in both winter periods. Higher quantities of ingested hay resulted in shorter grazing times both for sheep and fallow deer. SCHALITZ and FISCHER (1995) describe similar correlations for heifers kept outdoors in winter.

Table 7

Correlation coefficients (Pearson) between day light time, total ingestion time, and hay $(\mathrm{n}=18$ ), winter periods I, II, Paulinenaue location (Korrelationskoeffizienten [Pearson] zwischen Beobachtungszeitraum, Gesamtfressdauer, Grasensdauer und Heuaufnahmedauer [n=18], Winterperiode 1999/2000 und 2000/2001, Standort Paulinenaue)

\begin{tabular}{lllc}
\hline Characteristics & & Fallow deer & Sheep \\
\hline Day light time : Total ingestion time & $\mathrm{r}$ & 0.278 & 0.048 \\
& sign. & 0.265 & 0.850 \\
Day light time : Grazing time & $\mathrm{r}$ & 0.236 & -0.348 \\
& sign. & 0.347 & 0.157 \\
Day light time : Duration of hay intake & $\mathrm{r}$ & -0.001 & 0.464 \\
& sign. & 0.996 & 0.052 \\
Total ingestion time : Grazing time & $\mathrm{r}$ & $0.855^{* *}$ & $0.624^{*}$ \\
& sign. & 0.000 & 0.006 \\
Total ingestion time : Duration of hay intake & $\mathrm{r}$ & -0.019 & -0.198 \\
& sign. & 0.941 & 0.431 \\
Grazing time : Duration of hay intake & $\mathrm{r}$ & $-0.535^{*}$ & $-0.889^{* *}$ \\
& sign. & 0.022 & 0.000 \\
\hline
\end{tabular}

"Correlation is significant at a level of 0.05 (two-sided); ${ }^{* *}$ correlation is significant at a level of 0.01 (two-sided)

\section{Locomotion}

For the present study, the local position of the animal groups was marked at intervals of five minutes on a scale worksheet for later mathematical processing.

A comparison of the locomotion activities (Table 8) shows somewhat higher activities of both species in the first winter period. Both sheep and fallow deer showed lower locomotion activities in the second winter, which seems to correspond with the remarkably longer duration of hay intake.

The locomotion performance of grazing animals depends, inter alia, on the distribution of food sources, meteorological conditions, anthropogenic interference, and reproductive factors (rutting/rearing seasons). According to available literature, fallow deer spend between 7 and $11 \%$ of their time on locomotion activities (BAMBERG, 1985; ZEEB, 1990). 
Table 8

Comparison of mean locomotion data $\left(\mathrm{m} \cdot \mathrm{d}^{-1}\right)\left(\right.$ Mittelwertvergleich der Laufleistung $\left(\mathrm{m} \cdot \mathrm{d}^{-1}\right)$

\begin{tabular}{lcccc}
\hline Winter period & & Fallow deer & Sheep & Total year \\
\hline I & $\overline{\mathrm{x}}$ & 1409 & 1766 & $1587^{\text {n.s. }}$ \\
& $\mathrm{S}$ & 577.7 & 647.3 & $1193^{\text {n.s. }}$ \\
II & $\overline{\mathrm{x}}$ & 1399 & 988 & \\
& $\mathrm{~s}$ & 570.1 & 600.4 & \\
Total Species & $\overline{\mathrm{x}}$ & $1404^{\text {n.s. }}$ & $1377^{\text {n.s. }}$ & \\
\hline
\end{tabular}

Significant difference $(\mathrm{t}$-test) species and year $=407.30$; significant difference interactions $=576.00$; n.s. $=$ not significant

According to BAMBERG (1985), meteorological influences on the rhythm of daily activities are often closely related with climatic factors, seasonal, and local conditions. Fallow deer reduce both ingestion and locomotion activities at higher or lower temperatures. There is a negatively significant correlation coefficient between locomotion and hay intake of sheep (Table 9), whereas there is a positive correlation between grazing time and locomotion. In the environmental conditions as described, there is only an insignificant relationship between this characteristic and day light time or overall grazing time of sheep and fallow deer.

Table 9

Correlation coefficients (Pearson) between locomotion and day light time and characteristics of feed intake (Korrelationskoeffizienten [Pearson] zwischen Laufleistung und Länge des Lichttages sowie Merkmalen der Nahrungsaufnahmeaktivität)

\begin{tabular}{llcc}
\hline Locomotion : & & Fallow deer & Sheep \\
\hline Day light time & $\mathrm{r}$ & 0.249 & 0.052 \\
& sign. & 0.318 & 0.838 \\
Total ingestion time & $\mathrm{r}$ & 0.368 & 0.215 \\
& sign. & 0.133 & 0.392 \\
Grazing time & $\mathrm{r}$ & 0.319 & $0.517^{*}$ \\
& sign. & 0.197 & 0.028 \\
Hay intake time & $\mathrm{r}$ & -0.016 & $-0.523^{*}$ \\
& sign. & 0.951 & 0.026 \\
\hline
\end{tabular}

${ }^{*}$ Correlation is significant at a level of 0.05 (two-sided)

Traditionally, for many authors and notably activists involved in animal protection it seemed to be problematic to keep animals on fen areas in winter as they feared negative impacts on the health of the animals and harm to the sod (KLAPP, 1971). However, experience proves that it is possible to keep animals on such winter pastures and maintain both their performance and health if the number of animals is kept at a low level, and daily checks are guaranteed.

The animals use almost exclusively higher and, hence, drier areas for grazing. In this connection it is apparent that lasting effects of tread wear on fen depend on the varying level of surface water. Areas damaged by tread wear can be optically levelled by flooding the affected areas and the levelling effect produced by the animals' hoofs after the soil is dried.

According to SCHALITZ and FISCHER (1995), injuries of the sod by tread wear does not result in major environmental damage. On the one hand, sod symbiosis is characterised by intra-specific and inter-specific rivalry. On the other hand, however, predation and disturbances help to form and develop the vegetation (BEGON et al., 1991). 
Open spaces in the sod cover which are caused, among others, by tread wear bring about disturbances as established vegetation patterns are broken up, which gives other plants a chance to develop. Consequently, more soil seeds may develop and the botanical versatility of the affected areas improves (SCHALITZ et al., 2005).

\section{Acknowledgements}

The authors wish to thank Dr.Sylvia Ortmann from IZW Berlin for her critical reading of this paper and helpful suggestions.

\section{References}

ARNOLD, G.W.:

Comparison of the time budgets and circadian patterns of maintenance activities in sheep, cattle and horses grouped together. Appl. Anim. Behav. Sci. 13 (1984), 19-30

ARNOLD, G.W.; DUDZINSKI, M.L.:

Ethology of free-ranging domestic animals. Developments in animal and veterinary sciences, 2. Amsterdam 1978

BAILE, C.A.; DELLA-FERA, M.A.:

Nature of hunger and satiety control systems in ruminants. Central nervous system. J. Dairy Sci. 64 (1981), 1140-1152

BAMBERG, F.-B.:

Untersuchung von gefangenschaftsbedingten Verhaltensänderungen beim Damwild (Cervus dama Linne, 1758). Beiträge zur Wildbiologie 5 (1985), 24-33

BARTOS, L.; VANKOVA, D.; SILER, J.; LOSOS, S.:

Fallow deer tactic to compete over food with Red deer. Aggressive Behavior 22 (1996), 375-385

BEGON, M.E.; HARPER, J.L.; TOWNSEND, C.R.:

Ökologie. Heidelberg, Berlin, 1991

BUENO, L.; RUCKEBUSCH, Y.: Ingestive behaviour in sheep under field conditions. Appl. Anim. Ethol. 5 (1978), 179-187

CZAKO, J.; GAAL, M.; SANTHA, T.:

Adatok a juhok legelési viselkedéséhez [Examination of grazing behavior of sheep]. Allattenyész Anim. Breed. Budapest, hirlapkiadó Vállalat. 28 (1979), 363-371 [in Hungarian]

FISCHER, A.; LEIPNITZ, W.; SCHALITZ, G.:

Untersuchungen zu ausgewählten Leistungsparametern und Exterieurmerkmale der Skudde, Deutschlands kleinster Schafrasse. Arch. Tierz. 37 (1994), 643-650

FISCHER, A.:

Vergleichende Untersuchungen zum Verhalten von Wiederkäuern (Rind und Schaf) auf extensivierten Niedermoorweiden. Habil.-schrift, Landwirtschaftlich-Gärtnerischen Fakultät der Humboldt-Universität zu Berlin 2001

FISCHER, A.; SCHALITZ, G.; BEHLING, C.:

Breed specific classification potentials of sheep in different grassland biotopes. Arch. Tierz. 50

KLAPP, E.: (2007), 174-185

Wiesen und Weiden. Berlin u. Hamburg 1971

LEIPNITZ, W.:

Landschaftspflege mit Schafen im Havelländischen Luch bei Paulinenaue. Arch. Acker- u. Pflanzenb. u. Bodenk. 46 (2001), 425-435

MEEKERS, R.B.; MYERS, R.D.:

Patterns of food intake in the monkey during free or restricted feeding and in response to 2-DG or insulin injection. Physiol. Behav. 22 (1979), 563-574

PIETROWSKI, R.:

Untersuchungen zum Verhalten von Damwild bei nutztierartlicher Haltung. Diss. Rheinische Friedrich-Wilhelms-Universität, Bonn 1984

PORZIG, E.; SAMBRAUS, H.H. (Ed.):

Nahrungsaufnahmeverhalten landwirtschaftlicher Nutztiere. Berlin 1991

SCHALITZ, G.; FISCHER, A.:

Winterweide auf Niedermoor. Arch. Acker- u. Pflanzenb. u. Bodenk. 39 (1995), 45-52 
SCHALITZ, G.:

Versuchsführer. ZALF, Forschungsstation, Standort Paulinenaue 2001

SCHALITZ, G.; FISCHER, A.; BEHRENDT, A.:

Investigation into the development of substance contents in fodder and the landscape care effect of sheep on large-unit fen pastures. In: Conference Proceedings, International Conference on Sustainable Land Use in Intensively Used Agricultural Regions, 20.-23. September 2005, UFZ Centre for Environmental Research Leipzig

TEMBROCK, G.: Gesetzmäßigkeiten tierischen Verhaltens, in: SCHEIBE, K.-M. (Hrsg.): Nutztierverhalten. Jena 1987

TRIBE, D.E.: Influence of pregnancy and social facilitation on behaviour of the grazing sheep. Nature 166 (1950), 74

UECKERMANN, E.; HANSEN, P.: Das Damwild (Naturgeschichte, Hege, Jagd). Hamburg u. Berlin 1983

VAN ACKEN, D.:

Zum Tagesrhythmus des Damwildes. Ztschr. f. Jagdwiss. 18 (1972), 96-103

WASSMUTH, R.; MOORS, E.; LANGHOLZ, H.-J.:

Vitalität und Parasitenbefall von Schafen bei ganzjähriger Freilandhaltung. Arch. Tierz. 44 (2001)

ZEEB, U.: Special Issue, 230-239

Verhalten von Damwild bei nutztierartlicher Gehegehaltung unter Berücksichtigung des Aktivitäts rhythmus und der Reproduktion mit einem Vergleich zum Rotwild. Dissertation, Universität Stuttgart-Hohenheim 1990

Received: 2007-11-06

Accepted: 2008-06-03

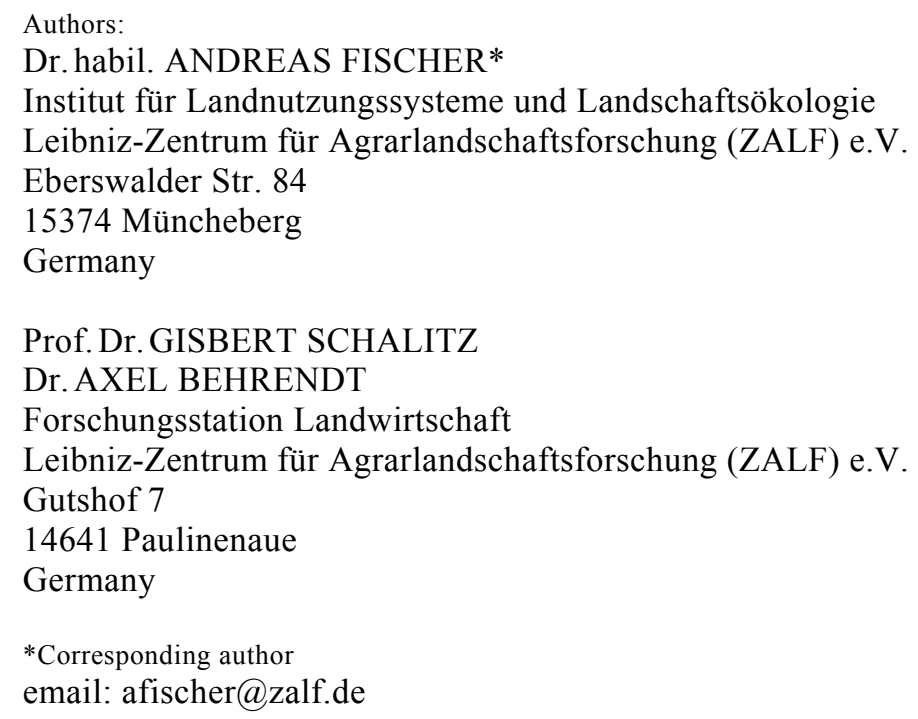

